\title{
IMAGINÁRIO E REPRESENTAÇÃO SOCIAL DA MARCA RIO NA COMEMORAÇÃO DOS 450 ANOS DA CIDADE: NARRATIVAS PARA O CONSUMO TURÍSTICO
}

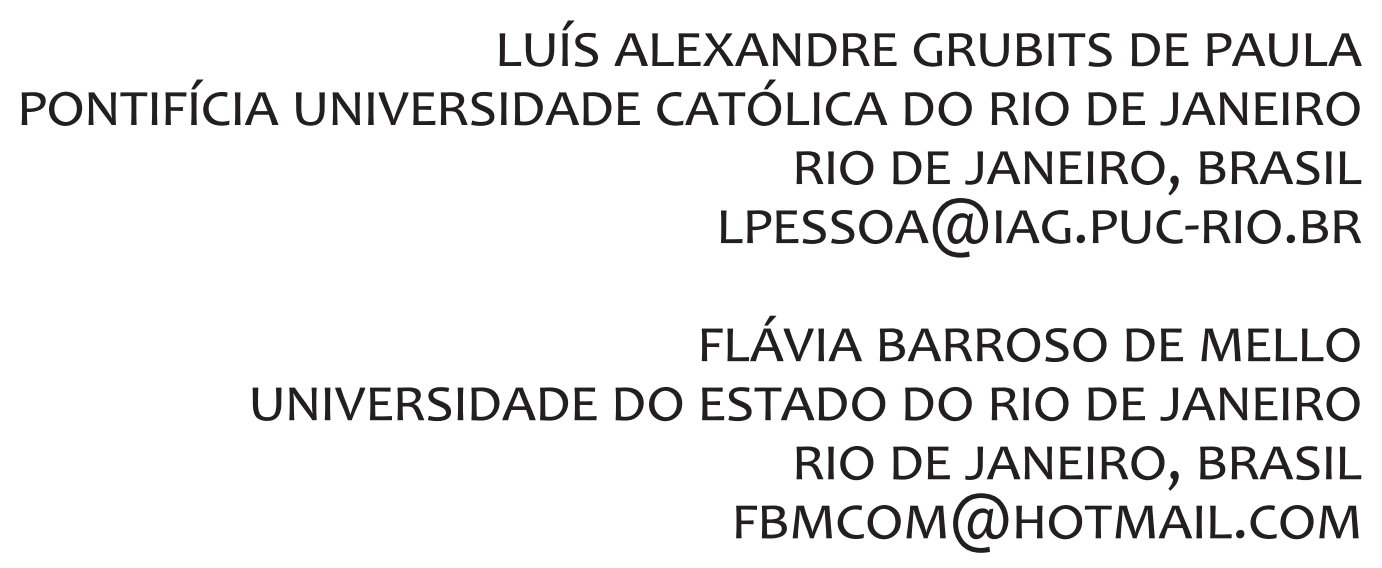

HTTP://DX.DOI.ORG/10.5902/2316882X22895 
IMAGINÁRIO E REPRESENTAÇÃO SOCIAL DA MARCA RIO NA COMEMORAÇÃO DOS 450 ANOS DA CIDADE: NARRATIVAS PARA O CONSUMO TURÍSTICO

Resumo: Conjugando teorias sobre imaginário, representação social e branding, este artigo estuda a marca "Rio" a partir de uma de suas manifestações, a marca "Rio 450 anos". A análise aponta que o percurso da marca privilegia a passagem da identidade individual para a coletiva, reforça seu imaginário festivo e o ethos de cidade espetáculo; indicando a estratégia de (re)inserção da cidade no circuito turístico internacional. Palavras-chave: Branding; Imaginário Urbano; Marca-cidade; Turismo; Representações Sociais.

IMAGINARIO Y REPRESENTACIÓN SOCIAL DE LA MARCA RIO EN LA CONMEMORACIÓN DE LOS 450 AÑOS DE LA CIUDAD: NARRATIVAS PARA EL CONSUMO TURÍSTICO

Resumen: Conjugando teorías acerca del imaginario, de la representación social y de la marca, este artículo estudia la marca "Rio" desde una de sus manifestaciones, la marca "Rio 450 años". El análisis señala que la construcción de la marca favorece la transición de la identidad individual a la colectiva, refuerza su imagen festiva y el ethos de ciudad espectáculo; lo que indica su estrategia de (re)inserción en el circuito turístico internacional.

Palabras clave: Branding; Imaginario urbano; Marca-ciudad; Turismo; Representaciones Sociales.

IMAGINARY AND SOCIAL REPRESENTATION OF THE BRAND RIO IN THE CELEBRATION OF THE 450TH ANNIVERSARY OF THE CITY: NARRATIVES FOR TOURIST CONSUMPTION

Abstract: Combining theories about imaginary, social representation and branding, this paper studies the brand "Rio" from one of its manifestations, the brand "Rio 450 years". The analysis shows that the construction of the brand favors the passage from individual to collective identity, reinforces its festive imagery and the ethos of spectacle city; indicating the strategy of the city to (re)insert itself in the international tourist circuit. Keywords: Branding; Urban imaginary; City-Brand; Tourism; Social Representations. 


\section{Introdução}

Ninguém sabe melhor do que tu, sábio Kublai, que nunca se deve confundir a cidade com o discurso que a descreve. No entanto, há uma relação entre ambos. (CALVINO, 1990)

Centradas no consumo, as sociedades contemporâneas reservam um lugar cada vez mais importante à procura de sentido, à construção de projetos de vida que as ajudem a dar uma orientação e um significado à sua experiência cotidiana, em um cenário social cada vez mais complexo e fragmentado. Consequentemente, neste contexto, a marca representa uma experiência, um estilo de vida e, principalmente, um repositório de significado (SEMPRINI, 2010; SHERRY JR., 2006). Sob a ótica do mercado, portanto, como arena de negociação, onde os hábitos de consumo (re)desenham as dinâmicas urbanas cotidianas, não é de se estranhar que mesmo lugares - cidades, países - possam ser observados como marcas.

Assim, em uma leitura que pressupõe a cidade como um campo simbólico de articulação de interesses políticos e econômicos (PESAVENTO, 2007), observa-se uma tendência, no Brasil e no mundo, de revalorização e reconstituição das cidades, de seus espaços internos, que passam a ser revestidos de imaginários coletivos que lhes servem de suporte comunicacional para a construção da marca-cidade e, consequentemente, para os possíveis investimentos e ações de comunicação, potencializando negócios em diversos segmentos da economia.

Com efeito, identifica-se o turismo como uma das importantes fontes de receita do Brasil. Mais especificamente, os megaeventos têm contribuído para atrair turistas de todas as partes do mundo, especialmente, no início do século XXI. Para Freitas e Lins (2014), é da natureza dos megaeventos que eles atuem como mídia, como poderosos veículos de comunicação, verdadeiras vitrines. Em grandes shows, por exemplo, tanto as divulgações que antecedem ao evento quanto o evento em si, tornam-se arenas de disputa de grandes marcas, pela possibilidade de se apropriarem da emoção do público que explode nas arenas e dos impactos causados fora delas para gerar a "contaminação do imaginário coletivo" (MAFFESOLI, 1998, p. 27). Os megaeventos, portanto, com suas expressões culturais e midiáticas, são importantes fenômenos geradores de sentido, que pontuam o espaço urbano e suas representações sociais.

Rev.Cad.Comun. Santa Maria, v.20, n.3, art 4, p.79 de 95, set/dez.2016 
Neste contexto, identifica-se o Rio de Janeiro, importante cidade do cenário econômico, social e cultural do Brasil, como protagonista dos principais megaeventos realizados no país, ao longo dos primeiros anos deste século, o que se configura em uma clara tentativa de revitalização da cidade. Nos grandes eventos promovidos, tanto pelo poder público como pela iniciativa privada, observa-se o foco na (re)construção e no fortalecimento da marca-cidade, que passa a ser revestida de simbolismos, valores, crenças e estilos de vida. É a cidade convertida em empresa e palco para o espetáculo: "o mundo presente e ausente que o espetáculo faz ver é o mundo da mercadoria dominando tudo que é vivido" (DEBORD, 1997, p.28).

Assim, para este trabalho, as comemorações dos 450 anos da cidade do Rio de Janeiro foram observadas como uma manifestação da "marca Rio", buscando conjugar as teorias que tratam de imaginário e representação social e as teorias de branding, em especial, a proposta de Semprini (2010). Com efeito, buscou-se interpretar os discursos construídos para reforçar os atributos da marca-cidade a partir dos significados articulados pela comunicação das comemorações dos 450 anos do Rio de Janeiro, indicando, assim, os esforços de marketing e de branding para (re)inserir a cidade no centro do turismo mundial.

Mais precisamente, optou-se pela análise da marca Rio 450, a partir da observação do conteúdo do site oficial do evento, http://www.rio450anos.com.br, de entrevista realizada com Ricardo Leite, sócio-fundador e CEO da Crama Design Estratégico (doravante, designada Crama), empresa responsável pela criação e desenvolvimento da marca Rio 450, e de consulta a documentos internos de trabalho da empresa disponibilizados para os autores.

\section{Imaginário e representações sociais na cidade}

Para pensar o tema das representações e linguagens sobre a cidade, parte-se da abordagem utilizada pela história cultural, mais especificamente do pensamento da historiadora Sandra Pesavento (2007, 2014). Para a autora, a cidade não é mais considerada como um lócus privilegiado da realização da produção ou da ação dos atores sociais, "mas, sobretudo, como um problema e um objeto de reflexão, a partir das representações sociais que produz e que se objetivam em práticas sociais." (PESAVENTO,

Rev.Cad.Comun. Santa Maria, v.20, n.3, art 4, p.80 de 95, set/dez.2016 
2007, p. 3).

Assim, concorda-se com Pesavento (2007) quando a autora afirma que para cada cidade real, concreta, visual, táctil, consumida e usada no dia-a-dia há outras tantas cidades imaginárias, representadas, ao longo do tempo, pela palavra escrita ou falada, pela música, pela imagem, pelas práticas cotidianas, pelos rituais e pelos códigos de civilidade de seus citadinos, pois

cidades são, por excelência, um fenômeno cultural, ou seja, integradas a esse princípio de atribuição de significados ao mundo. Cidades pressupõem a construção de um ethos, o que implica a atribuição de valores para aquilo que se convencionou chamar de urbano. (PESAVENTO, 2007, p. 3)

Muito mais do que uma aglomeração de concreto, portanto, a cidade é um campo simbólico, em que se travam lutas políticas, jogos de representações, identidades e relações de poder, em processo contínuo de construção. Como sugere Castells (1996, p. 157),

a cidade, entendida não somente como território que concentra um importante grupo humano e uma grande diversidade de atividades, mas também como um espaço simbiótico (poder político-sociedade civil) e simbólico (que integra culturalmente, dá identidade coletiva a seus habitantes e tem um valor de marca e de dinâmica com relação ao exterior), converte-se num âmbito de respostas possíveis aos propósitos econômicos, políticos e culturais de nossa época.

Como suportes ou (re)produtores de discursos que contribuem para a formação de imagens que circulam nas cidades contemporâneas, os meios e recursos de comunicação ecoam as narrativas que reforçam ícones e símbolos que carregam, para dentro e para fora do país, o imaginário da cidade e dos seus citadinos. Como afirma Canclini (2005, p. 117),

os referentes de identidades se formam, agora, - mais do que nas artes, na literatura e no folclore, que durante séculos produziram os signos de diferenciação das nações - em relação com os repertórios textuais e iconográficos gerados pelos meios eletrônicos de comunicação e com a globalização da vida urbana.

No Rio de Janeiro, é possível identificar, através das narrativas midi- 
áticas, como apontam Freitas, Gotardo e Sant'Anna (2015), várias visões da cidade em momentos distintos da construção de sua marca: em 2007, identificam-se as representações da violência na mídia que construíam uma atmosfera de medo ligado especialmente ao tráfico e à favela. Em 2012, no entanto, após diversos esforços (ações governamentais e mercadológicas), a favela torna-se parte do "ser carioca", trazendo um novo elemento de consumo turístico para a cidade. Do mesmo modo, pressupõe-se, no presente trabalho, que a estratégia montada para a comemoração dos 450 anos do Rio, portanto, é uma concretização de um determinado imaginário (dentre muitos possíveis) a serviço de uma ordem ideológica (e consequentemente, política e econômica) direcionada pelos imperativos de mercado. Finalmente, a construção de narrativas sobre a 'cidade ideal', a modernidade almejada e o espetáculo a ser consumido é, no entender de Jaguaribe (2011), uma das formas de tornar a cidade visível e identificável no imaginário global, por meio de intensos investimentos publicitários. Dentre esses investimentos, pode-se identificar os esforços de construção e gestão de marca, conhecidos como branding, que são abordados na próxima seção.

\section{Marca, marca de país e marca-cidade}

Partindo de uma concepção contemporânea, o termo marca vai além da definição de símbolos e designs isolados, passando a ser entendido como a junção de tudo o que compõe e o que não compõe a sua estratégia (BEDBURY, 2002; CALKINS, 2006). Para Semprini (2010), a marca pós-moderna é um conceito maior do que suas manifestações isoladas, "é o conjunto de discursos relativos a ela pela totalidade de sujeitos envolvidos em sua construção. É uma instância semiótica, uma maneira de segmentar e de atribuir sentido de forma ordenada, estruturada e voluntária" (SEMPRINI, 2010, p.96). Portanto, na visão do autor, o papel dos destinatários da marca "está longe de ser aquele de espectadores passivos e, sobretudo, a marca funciona como um verdadeiro agente de mediação." (SEMPRINI, 2010, p. 184).

Tradicionalmente associadas a produtos e serviços, as atividades relacionadas ao branding (gestão de marcas, produtos, serviços, comunicação publicitária) têm despertado, mais recentemente, o interesse de governos de todas as instâncias (países, cidades, bairros, regiões), em função

Rev.Cad.Comun. Santa Maria, v.20, n.3, art 4, p.82 de 95, set/dez.2016 
do processo de globalização e crescente competição internacional. (GlRALDI; CRESCITELLI, 2006). A construção de uma marca para um país, uma cidade ou um território está baseada nas teorias relacionadas ao city branding, place branding ou destination branding, todas compostas por estudos relativamente recentes, mas que convergem para um mesmo objetivo: construir uma reputação mercadológica para marcas locais a partir da "representação perceptual das ações passadas e expectativas futuras que descrevem o atrativo geral do território para seus grupos de interesse em comparação a seus competidores" (GARCÍA; GÓMEZ; MOLINA, 2013, p.112).

Assim, todo o processo de gestão, seja de marca-produto ou marca-lugar, está intimamente ligado à gestão da imagem que se procura que consumidores tenham dessa marca. E a construção dessa imagem, da identidade local, está diretamente relacionada ao seu passado e ao atual ambiente político, econômico, legal e cultural em que o lugar está inserido. Nesse sentido, cada nação já é uma marca, pois existe na mente das pessoas como uma entidade com atributos positivos e negativos (KYRIACOU; CROMWELL, 2005, apud Giraldi; Crescitelli, 2006), passível ou não de gestão.

Assim, nas palavras de Pesavento (2007, p.4),

a cidade sensível é aquela responsável pela atribuição de sentidos e significados ao espaço e ao tempo que se realizam na e por causa da cidade. É por esse processo mental de abordagem que o espaço se transforma em lugar, ou seja, portador de um significado e de uma memória; que passamos a considerar uma cidade como metrópole, realidade urbana que, desde o seu surgimento, causou uma revolução na vida, no tempo e no espaço; que criamos as categorias de cidadão e de excluído para expressar as diferenças visíveis e perceptíveis no contexto urbano fazendo com que se criem novas identidades a partir do gesto, do olhar e da palavra que qualifica; que falamos de progresso ou de atraso, que distinguimos o velho do antigo; que construímos a noção de patrimônio e instauramos ações de preservação, ou, em nome do moderno, que redesenhamos uma cidade, destruindo para renovar.

Especialmente, na última década, é possível observar a gestão da marca local em países como a Escócia, a Nova Zelândia, a Espanha, a Alemanha e os EUA, em cidades como Paris e Nova lorque e em regióes como o 
Arizona, os Pirineus ou Vale do Silício, tendo como objetivo fundamental a apropriação de valores e representações, para si e seus moradores, a fim de construir uma imagem para o lugar que seja condizente com o cenário internacional onde este queira se inserir. No caso do Rio de Janeiro, cidade objeto desta análise, não é possível identificar uma gestão de marca formal, mas observa-se que a Prefeitura e os diversos agentes de mercado (empresas, produtores e veículos de mídia) têm se apropriado do imaginário social para construir a marca Rio a partir dos significados e argumentos que são (re)articulados pelos megaeventos realizados na cidade do Rio de Janeiro, desde o início do século XXI.

A partir, portanto, dessa dinâmica de representações, identidades e relações de poder, a cidade "ganha mais reconhecimento, visibilidade nacional e internacional, além de narrativa própria, como marca de si mesma (Marca Rio, um tipo de grife) e cidade que marca quem a visita e quem nela mora, com sua exuberância de eventos e megaeventos." (FREITAS; GOTARDO; SANT'ANNA, 2015, p. 4)

O esforço para efetivar a vocação de "cidade espetáculo", e, consequentemente, de cidade também vocacionada para o turismo urbano, no entanto, remonta ao começo do século XX, com a Exposição Nacional de 1908, que foi o primeiro megaevento que a cidade recebeu, pós-Reforma Passos (FREITAS; FORTUNA, 2013). Depois, vieram a Exposição Internacional de 1922 e a Copa do Mundo de 1950. Mais recentemente, a Eco-92 (Conferência das Nações Unidas sobre o Meio Ambiente e o Desenvolvimento), cinco edições do Rock in Rio (1985/1991/2001/2011/2015) - e uma prevista para 2017 -, os Jogos Pan-Americanos, de 2007, os Jogos Mundiais Militares, de 2011, a Rio+20, em 2012, a Jornada Mundial da Juventude, em 2013, a Copa das Confederações, em 2013, a Copa do Mundo, em 2014 e, finalmente, a cidade está prestes a sediar as Olimpíadas, que já tem alterado a dinâmica e o cotidiano dos citadinos.

Todos esses eventos podem ser entendidos como manifestações da “marca Rio", pela ótica de Semprini (2010), em seu modelo projeto/manifestação de identidade da marca. O modelo pode ser expresso por um processo no qual os gestores da marca concebem um sentido primordial, denominado projeto de marca, que é caracterizado então por suas manifestações. As manifestações da marca são os enunciados que tornam concreto o projeto de marca, são formas tanto materiais quanto imateriais de tornar a marca perceptível aos destinatários através da observação ou

Rev.Cad.Comun. Santa Maria, v.20, n.3, art 4, p.84 de 95, set/dez.2016 
da experiência. Podem ser a estratégia, o produto em si, a embalagem, o preço, logomarcas, eventos, entre outros.

Nesse sentido, as comemorações do aniversário de 450 anos do Rio de Janeiro são também consideradas uma manifestação da marca Rio. Ao longo dos 12 meses de 2015, a cidade foi vestida com ações e eventos que celebraram a data, o que, talvez, tenha representado a manifestação mais genuína da marca Rio, inclusive por sua "característica autóctone”, quando comparada a maior parte dos megaeventos anteriormente citados.

É fundamental observar que a "cidade" é um objeto muito menos circunscrito para a gestão de marca do que os objetos que, em geral, são alvo da teoria de branding (produtos, serviços, comunicação publicitária). Portanto, neste artigo, parte-se do pressuposto de que se há uma gestão da "marca Rio", a prefeitura privilegia, em sua comunicação, ações que reforçam alguns dos ícones e símbolos da cidade que carregam, para dentro e para fora do país, o imaginário carioca. Como sugere Sanchez (2010, p. 91), "há uma necessidade política de reciclar permanentemente a imagem agregando novos significados a ela", resgatando e mantendo as "marcas da cidade que se pretendem memoráveis".

\section{Análise da marca Rio 450: valores, narrativa e discurso}

O estudo aqui apresentado segue a proposição de Semprini (2010) para a análise das manifestações de marca, partindo dos aspectos mais abstratos, os valores e as narrativas da marca Rio 450, para chegar aos mais concretos e tangíveis, os discursivos, a fim de entender os significados do objeto de estudo deste trabalho.

Deve-se observar, de início, que, para a gestão do projeto das comemorações dos 450 anos da cidade a Prefeitura do Rio de Janeiro instituiu o "Comitê 450 anos". Tal Comitê foi formado por funcionários públicos e colaboradores contratados no mercado privado (para efeito de simplificação, ao longo do texto, o Comitê é designado Prefeitura).

Segundo documentos da Crama, o briefing recebido da Prefeitura remete ao sucesso da marca criada para a comemoração do IV Centenário da cidade - formada por quatro números “4”, em um design de Aluísio Magalhães (Figura 1), de inspiração modernista - que foi adotada de forma irrestrita pela população e pela mídia da época, em um tempo em que não havia internet e a televisão possuía alcance muito mais restrito.

Rev.Cad.Comun. Santa Maria, v.20, n.3, art 4, p.85 de 95, set/dez.2016 


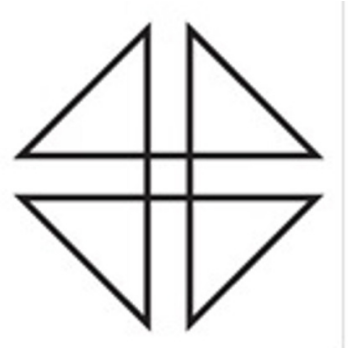

Figura 1 - Marca para as comemorações do IV Centenário da cidade do Rio de Janeiro

Fonte: CRAMA (2014)

Já em 1965, observa-se o imaginário de cidade festiva e o papel dos grandes eventos na construção desse imaginário, uma vez que nas comemorações do IV Centenário foram realizados um desfile temático de escolas de samba, o concurso da Rainha do IV Centenário e uma corrida de automóveis, que ficaram na memória e nos livros. Além disso, a marca do evento permanece, até hoje, em endereços como a Estrada Velha da Pavuna, em Del Castilho, onde está o Condomínio IV Centenário; a calçada da Rua da Estrela (em frente ao Hospital do Amparo Feminino), no Rio Comprido; a Rua Nova Jerusalém, em Bonsucesso, onde está a Escola Municipal IV Centenário; e a Rua Sargento João Lopes, na llha do Governador, numa loja de material eletrônico (AUTRAN; CANDIDA, 2013). O IV Centenário, portanto, ficou na memória afetiva dos citadinos.

Segundo Semprini (2010), a marca é o ponto culminante do encontro de três dinâmicas diferentes, a da produção, a da recepção e a dos elementos contextuais. Dessa forma, é fundamental destacar que o cenário social e político que permearia as celebrações do Rio 450 anos seria o de pós-manifestações de junho de 2013, que refletiam a insatisfação da população com o poder público. É interessante observar que, apesar da defasagem de cinquenta anos, o cenário atual guarda semelhanças com o do IV Centenário. Na década de 1960, o país sofreu o golpe militar; a cidade do Rio de Janeiro perdeu a condição de capital, após quase 200 anos; Carlos Lacerda havia sido eleito Governador do Estado da Guanabara e se esforçava para provar que sua gestão era eficiente; e, finalmente, a turbulência com grandes obras públicas marcava o cotidiano da cidade.

No contexto contemporâneo, a Prefeitura esperava que a marca para a comemoração dos 450 anos repetisse ou ampliasse o resultado de outrora. O briefing, portanto, apontava para alguns desafios, assim traduzidos pelos criadores da marca:

Rev.Cad.Comun. Santa Maria, v.20, n.3, art 4, p.86 de 95, set/dez.2016 
Como criar uma marca que estivesse à altura da comemoração dos 450 anos de uma cidade dita 'maravilhosa'? Como criar a marca para comemorar um estilo de vida, um DNA múltiplo e singular? Como mostrar o perfil de quem tem orgulho de ser o que é, cheio de ginga e de personalidade? Como mostrar o perfil que fosse ao mesmo tempo de todos os cariocas, mas que pudesse representar o que cada um tem de mais essencial? (CRAMA, 2014)

Em resumo, o briefing solicitava uma marca que o carioca abraçasse e aceitasse como sua, que o representasse. Além disso, deveria provocar um sentimento de conjugação entre individualidade e coletividade, refletindo, dessa forma, a cultura carioca e suas representações, porém inserida na atual organização da sociedade em rede digitalizada.

Nesse ponto da análise, é possível identificar os valores da marca: a individualidade de cada citadino e a identidade coletiva do carioca, colocadas em estado de conjunção. Ou seja, o protagonista da narrativa de marca seria o cidadão carioca, mais do que a própria cidade, escapando assim das representações da cidade de natureza exuberante apenas, como é possível observar nas marcas dos grandes eventos realizados no Rio de Janeiro nas últimas décadas, baseadas, quase sempre, em leituras da paisagem do Pão de Açúcar e da Baía de Guanabara. São exemplos as marcas dos Jogos Pan-Americanos e Parapan-Americanos de 2007 e dos Jogos Olímpicos e Paralímpicos de 2016 (Figura 2).
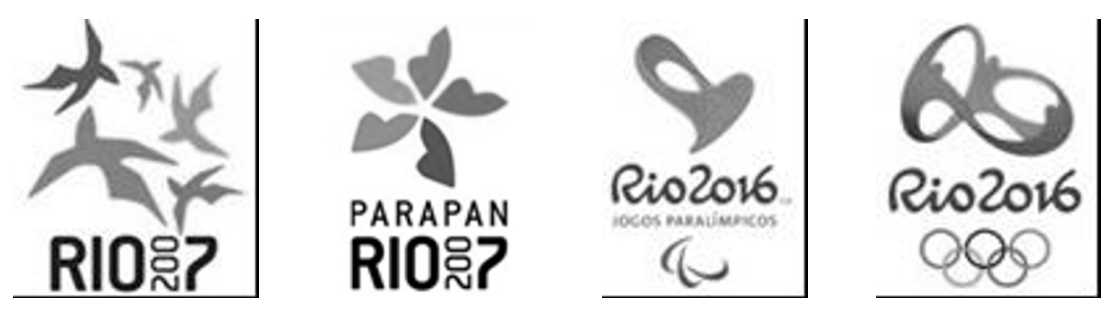

Figura 2 - Marcas dos Jogos Pan-Americanos e Parapan-Americanos de 2007 e dos Jogos Olímpicos e Paralímpicos de 2016

Fonte: CRAMA (2014)

Em síntese, a marca deveria traduzir o "carioca do Rio" antes mesmo do "Rio do carioca" (CRAMA, 2014), refletindo um imaginário marcado pelo otimismo, pela informalidade, pela simpatia e pelo pertencimento (por nascimento ou escolha) a essa cultura, como identifica o site, ao explicar a personalidade e o "tom de voz" da marca: 
Otimismo: pode chover a semana inteira, mas a gente sempre acredita que no domingo vai dar praia. A gente prefere o 'sim' ao 'não'; gosta mais do ponto de exclamação do que das reticências; e prefere expressões positivas, mais do que qualquer outra coisa. Informalidade: a gente quer se comunicar da Zona Sul à Zona Norte, da favela ao asfalto. (...) Uma boa dose de simplicidade é sempre bem-vinda para todo mundo se sentir em casa. Simpatia: nossa marca tem voz alegre e próxima. Não importa se é um primeiro encontro, ela vai falar com você como se já te conhecesse há um tempão (...). Orgulho: o sentimento vale para quem é carioca da gema ou de coração. Somos apaixonados pelas coisas mais simples, e isso se traduz em convicção e energia no tom de voz da marca. Gostamos de afirmar, de nos posicionar e de valorizar o lado bom de tudo. (http://www.rio450anos.com.br)

Passando ao nível narrativo do modelo proposto por Semprini (2010), deve-se identificar como os valores da marca Rio 450 são colocados em forma de relato, considerando que uma narrativa pode ser definida, de maneira simples, como uma sucessão de estados de um sujeito, indicando uma transformação.

Nesse sentido, a proposta de conjugar os valores individuais de cada citadino e a identidade coletiva do carioca, levou ao desenvolvimento de "uma marca narrativa, que convida a todos a estarem em torno de uma mesma ideia. Que integra, pois traduz um Rio que respeita as diferenças e promove expressões individuais." (CRAMA, 2014)

No briefing recebido da Prefeitura, solicitava-se a criação de uma marca que refletisse a cultura carioca, e, sobretudo, alinhada com a atual organização da sociedade em rede digitalizada. Para tal, a Crama propôs uma "narrativa para novas conquistas", pois

tudo já foi dito sobre o que vivemos nos últimos 450 anos, mas uma cidade é um organismo vivo que deve reafirmar seus valores e potenciais, renovar o compromisso com as expectativas de suas pessoas e reorganizar seus significados para os próximos tempos (CRAMA, 2014).

A narrativa da marca Rio 450 pode ser definida, portanto, com uma "narrativa compartilhada" entre os diferentes sujeitos - Prefeitura, empresas, citadinos e, por que não dizer, a própria cidade humanizada - colocados em interação na celebração dos 450 anos do Rio de Janeiro.

Rev.Cad.Comun. Santa Maria, v.20, n.3, art 4, p.88 de 95, set/dez.2016 
A análise chega, assim, ao nível dos discursos ou das manifestações, aquele no qual os valores e narrações são enriquecidos e concretizados pelas figuras do mundo: objetos, formas, cores, personagens, estilos, slogans, logos, etc. Nas palavras de Semprini (2010, p. 168), “este nível é, com certeza, o mais sensível ao ambiente sociocultural, aos modos de vida e ao comportamento dos receptores". Deve-se observar que, neste nível, se situam os "códigos" ou os "atributos" das marcas que, apesar de serem de grande importância para seu reconhecimento e impacto, só têm pertinência por garantir a concretização dos valores e narrativas da marca, suas verdadeiras fontes de identidade.

Com efeito, partindo dos três números da celebração, a Crama concretiza o discurso abstrato analisado até esse ponto e constrói o símbolo de uma marca que dá vida ao personagem “carioca do Rio", lançando, assim, oficialmente a marca no dia do aniversário do Rio de Janeiro, em primeiro de março de 2015 (Figura 3).

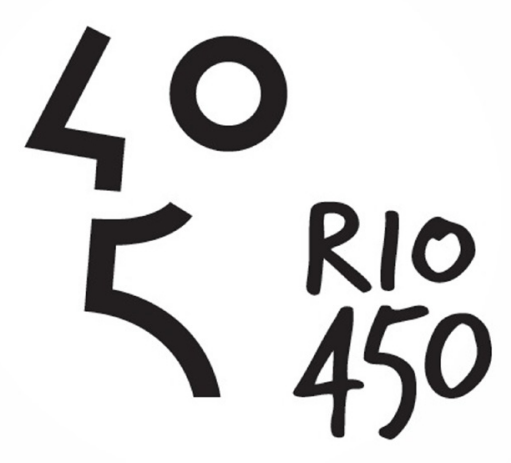

Figura 3 - Marca Rio 450

Fonte: Site oficial Rio 450 anos (2015)

Embasado no conceito de co-criação de conteúdo, o nível discursivo da marca Rio 450 tem características de "marca aberta". Seus traços denotam uma malha construtiva simples, de menor apelo decorativo do que as marcas dos grandes eventos sediados no Rio nos últimos anos. Sua simbologia é acessível e de entendimento imediato.

Se a marca do IV Centenário do Rio caracterizou-se pelo engajamento popular, a marca Rio 450, fiel aos conceitos vigentes de sociedade em rede, se propõe a ser uma plataforma de compartilhamento e de "viralização". A esse respeito deve-se observar, ainda, que atualmente o branding preocupa-se menos com a construção de logos e mais com as experiências do consumidor com as marcas. Resgatando a natureza semiótica da 
marca (SEMPRINI, 2010), pode-se dizer que a marca contemporânea se constrói na sua interação com o receptor, é, antes de tudo, uma marca experienciada.

Aplicando este conceito ao nível discursivo da marca, a marca Rio 450 foi construída para aceitar interferências gráficas de maneira planejada ou livre e ganha vida e significado pleno somente quando cada pessoa ou instituição cria sua versão pessoal. Isso pode acontecer nas plataformas digitais (internet, em especial no site oficial, com a possibilidade de uso livre da marca nas redes sociais), em intervenções urbanas (pintura de muro, grafite, adesivagem em materiais diversos, etc.) e na customização de objetos do cotidiano (silk ou pintura em camiseta, bordado em bolsa, etc.), como ilustrado nas Figuras 4 e 5 .

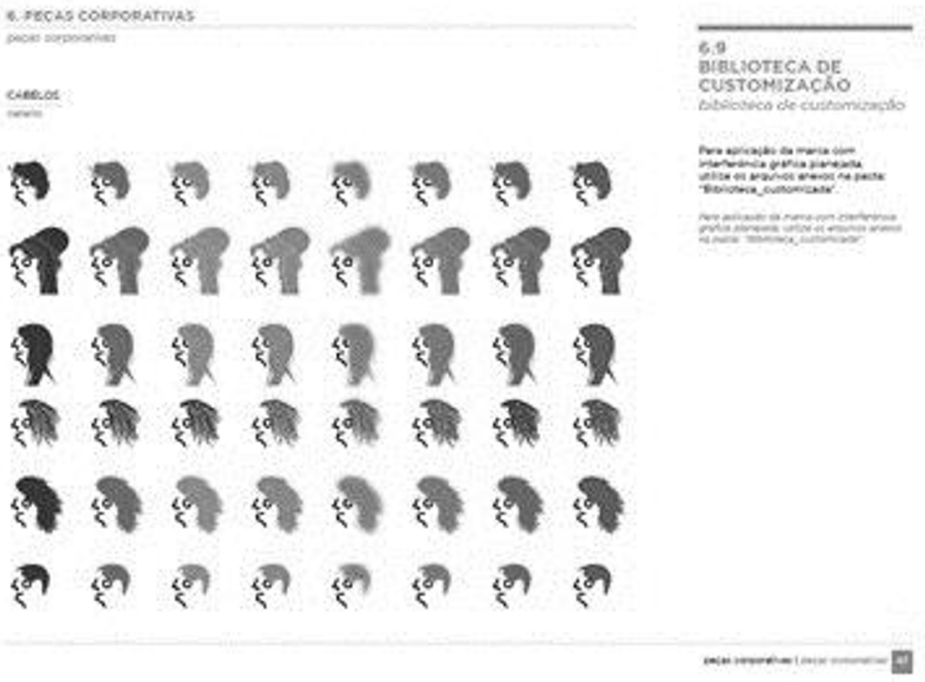

Figura 4 - Biblioteca de customização do site oficial Fonte: Site oficial Rio 450 anos (2015)
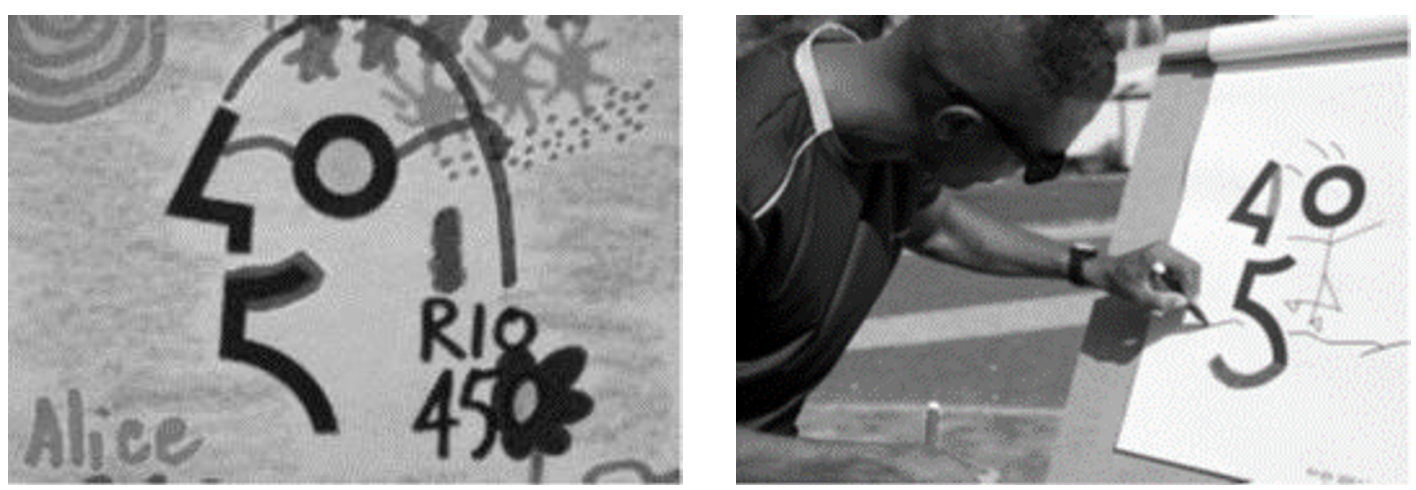

Figura 5 - Manifestações populares

Fonte: CRAMA (2015)

O conceito de "marca aberta" foi transferido não apenas para a relação da marca com o cidadão, mas, também, com empresas ou qualquer Rev.Cad.Comun. Santa Maria, v.20, n.3, art 4, p.90 de 95, set/dez.2016 
outro agente da sociedade. Montadoras de carro, supermercados, vestuário e calçados foram alguns dos muitos segmentos econômicos cujas empresas fizeram uso da marca Rio 450 para lançar novos produtos (como o Novo FIAT Uno 450 e a sandália Ipanema Rio) ou apenas fazer anúncios de oportunidade utilizando a marca (Zona Sul e Coca-Cola, por exemplo).

Além disso, a marca Rio 450 dialogou com os grandes eventos do calendário da cidade como o Reveillon 2105 e o Carnaval 2015 (Figura 6).
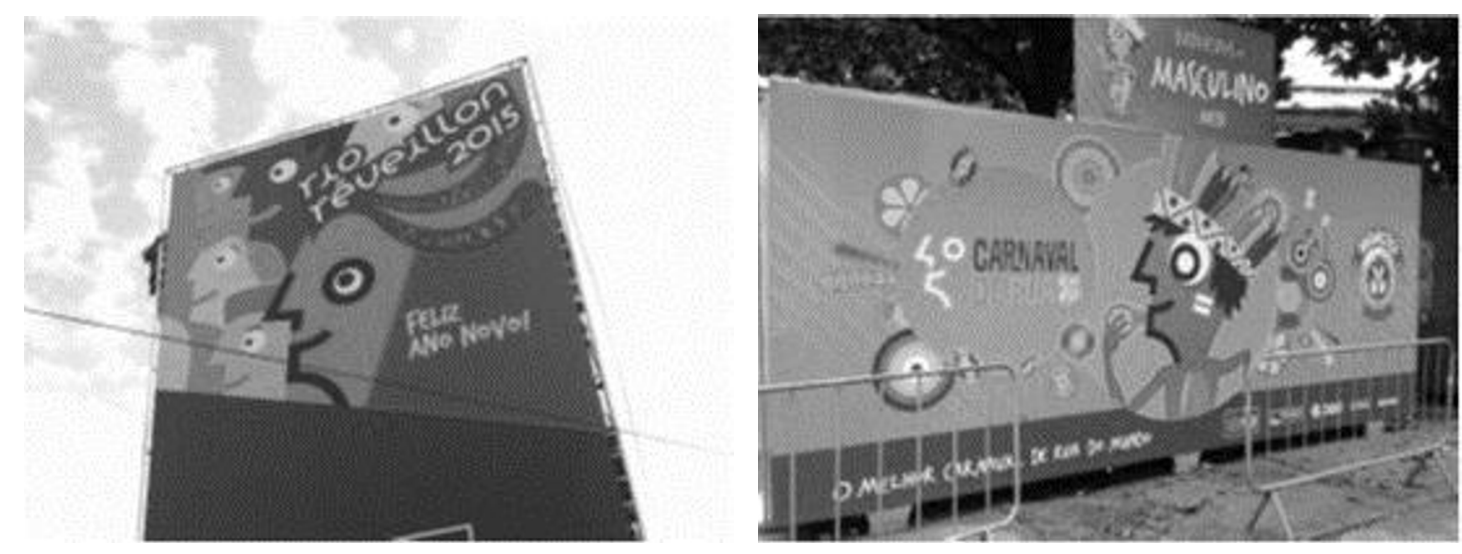

Figura 6 - Aplicação com as marcas do Reveillon e do Carnaval 2015

Fonte: CRAMA (2015)

Concretiza-se, portanto, a construção de uma marca que, ao pretender homenagear os 450 anos da cidade, apresenta-se como um rico objeto para entender os significados (em contínua construção) do imaginário e da representação social da Marca Rio, em um contexto de esforços de marketing e de branding para inserí-la no mercado de turismo nacional e internacional.

\section{Considerações finais}

A partir da análise da marca Rio 450, entendida aqui como uma manifestação ou sub-marca da marca Rio, verifica-se que ao agrupar em torno do tema 450 anos diversos eventos e outras atividades culturais, provoca-se um efeito de engrandecimento, uma espécie de apropriação da lógica dos megaeventos para a comemoração do aniversário da cidade. No passado distante, talvez, essa data fosse comemorada em um evento único, em algum espaço icônico da cidade. Mas, no contexto de cidade espetáculo e dos megaeventos, a comemoração ganha contornos espaciais e temporais estendidos e intensificados.

De certo modo, o Rio é, para dentro e para fora do país, represen-

Rev.Cad.Comun. Santa Maria, v.20, n.3, art 4, p.91 de 95, set/dez.2016 
tado e reconhecido como uma cidade festiva, de natureza exuberante e com um povo simpático, informal e otimista, num imaginário, como sugere Maffesoli (2001, p. 76) "que ultrapassa o indivíduo, que impregna o coletivo ou, ao menos, parte do coletivo." Esse traço já se manifestava na comemoração do IV Centenário e de outros grandes eventos realizados na história da cidade, como apontado neste trabalho, comprovando, assim, a vocação de cidade espetáculo, que se amplificou no começo do século $X X I$, na cultura dos megaeventos.

O marketing urbano, no entender de Sanchez (2010), permite identificar as profundas conexões entre os campos da cultura, da comunicação e da política que atuam na cidade para tornar hegemônicas determinadas leituras do espaço. Com efeito, percebe-se no processo de construção da marca Rio 450, um processo de exacerbação de aspectos estereotipados do imaginário da cidade (como o otimismo e a informalidade), que passam ao largo das incongruências do processo de pacificação das comunidades carentes (já incorporadas nos roteiros turísticos "exóticos" oferecidos aos visitantes) e das desigualdades sócio-econômicas características do Rio. Tal "leitura do espaço" ajusta-se com precisão ao processo de branding da cidade, que implica em vender a imagem de bom destino para recursos, investimentos e turismo, gerando ganhos simbólicos e econômicos. Nesse sentido, vale destacar o conceito de "marca aberta" adotado para o Rio 450 anos; aberta não apenas ao cidadão, mas, também, às empresas e a outros agentes de mercado, fortalecendo a imagem do Rio de Janeiro no contexto de cidade-mercado e, consequentemente, sua imagem no cenário internacional em que busca se inserir.

Futuras pesquisas, a partir do presente trabalho, poderiam abordar a marca Rio 450 a partir de outros olhares, como por exemplo, pelo viés do receptor, explorando as possíveis identificações, ou não, que diferentes sujeitos têm com a marca e suas manifestações.

Finalmente, é a partir do "carioca do Rio" que a marca Rio 450 apresenta o "Rio do carioca". É a passagem do individual para o coletivo que o percurso da marca (dos valores e narrativas abstratos aos traços concretos) ilustra, evidenciando, dessa forma, a reinvenção simbólica da cidade a serviço da ordem do mercado, com o objetivo explícito de atrair tanto consumidores externos quanto de alargar o nível de consumo interno. 


\section{REFERÊNCIAS}

AUTRAN, P.; CANDIDA, S. A marca atemporal do $4^{\circ}$ Centenário. O Globo, Rio de Janeiro, 07/12/2013. Disponível em: <http://oglobo.globo.com/rio/a-marca-atemporal-do-4-centenario-11005284>. Acesso em 01 jun. 2015.

BEDBURY, S. O novo mundo das marcas. Rio de Janeiro: Campus, 2002.

CALKINS, T. O desafio do Branding. In: TYBOUT, A. M.; CALKINS, T. (orgs.) Branding: fundamentos, estratégias e alavancagens de marcas. São Paulo: Atlas, 2006.

CALVINO, I. As Cidades Invisíveis. São Paulo: Companhia das Letras, 1990.

CANCLINI, N. G. Narrar o multiculturalismo. In: Consumidores e Cidadãos: conflitos multiculturais da globalização. Rio de Janeiro: Editora da UFRJ, 2005, pp. 113-126.

CASTELLS, M. As cidades como atores politicos. Novos Estudos CEBRAP, n.45, jul. 1996, pp. 152-166.

CRAMA DESIGN ESTRATÉGICO, Documento interno, 2014.

CRAMA DESIGN ESTRATÉGICO, Documento interno, 2015.

DEBORD, G. A Sociedade do espetáculo: comentários sobre a sociedade do espetáculo. Rio de Janeiro: Contraponto, 1997.

FREITAS, R. F.; FORTUNA, V. O. Rio de Janeiro: a comunicação e a construção da cidade-espetáculo. Revista Latinoamericana de Ciencias de la Comunicación, vol.10, n.18, jan./jul. 2013, pp. 228-237.

FREITAS, R.F.; GOTARDO, A.T.; SANT'ANNA, C.N. Ativos intangíveis na marca Rio: o consumo turístico da cidade nos documentários internacionais. In: XXIV Encontro Nacional COMPOS, 2015, Brasília, Anais... Brasília: COMPÓS, 2015.

FREITAS, R. F.; LINS, F. Rock in Rio: eternamente jovem. Comunicação, Mídia e Consumo, vol. 11, n.32, set./dez. 2014, pp. 13-29. 2014

GARCÍA, J. A.; GÓMEZ, M.; MOLINA, A. Posicionamiento de marcas-destino: uma aplicación en cinco regiones españolas. INNOVAR. Revista de Ciencias Administrativas y Sociales, vol. 23, n. 50, octubre-diciembre 2013, pp. 111-127.

GIRALDI, J. M. E., CRESCITELLI, E. Desenvolvimento de Marca-País: uma Abordagem Teórica sobre as Dificuldades e Similaridades com o Desenvolvimento de Marca para Produtos. In: II Encontro de Marketing da ANPAD, 2006, Rio de Janeiro, Anais...Rio de Janeiro: AnPAD, 2006.

JAGUARIBE, B. Imaginando a Cidade Maravilhosa: modernidade, espetáculo e espaços urbanos. In: XX Encontro Nacional COMPÓS, 2011, Porto Alegre. Anais... Disponível ém <http://www.compos.org.br/data/biblioteca_1694.doc>. Acesso em 09 fev. 2014. 
CADERNOS DE COMUNICAÇÃO

UNIVERSIDADE FEDERAL DE SANTA MARIA

LEITE, R. Entrevista concedida a Flávia Barroso de Mello. Rio de janeiro, 10 jun. 2015.

MAFFESOLI, M. O tempo das tribos: o declínio do individualismo nas sociedades de massa. Rio de Janeiro: Forense Universitária, 1998.

MAFFESOLI, M. O imaginário é uma realidade. Revista FAMECOS, n.15, agosto/2001, pp. 74-82.

PESAVENTO, S. J. Cidades visíveis, cidades sensíveis, cidades imaginárias. Revista Brasileira de História, vol. 27, n. 53, jun./2007, pp. 11-23.

PESAVENTO, S. J. História e História Cultural. Belo Horizonte: Autêntica Editora, 2014.

RIO 450 ANOS. Disponível em: <http://www.rio450anos.com.br>. Acesso em 20 jun. 2015 .

SANCHEZ, F. A reinvenção das cidades para um mercado mundial. Chapecó, SC: Argos, 2010.

SEMPRINI, A. A marca pós-moderna: poder e fragilidade da marca na sociedade contemporânea. São Paulo: Estação das Letras e Cores, 2010.

SHERRY JR, J.F. Significado da Marca. In: TYBOUT, A. M.; CALKINS, T. (orgs.) Branding: fundamentos, estratégias e alavancagens de marcas. São Paulo: Atlas, 2006, p.40-69. 


\section{Resumo sobre o autores:}

Luís Alexandre Grubits de Paula Pessôa

Doutor em Letras (Universidade Presbiteriana Mackenzie, 2010), Mestre em Administração de Empresas (PUC-Rio, 1996) e Economista (UFRJ, 1993). Professor Adjunto da PUC-Rio, onde leciona nos Programas de Pós-Graduação e de Graduação em Administração. Coordenador Acadêmico do MBA em Marketing da PUC-Rio. Possui ampla experiência como executivo de empresas nas áreas de comunicação e marketing.

Flávia Barroso de Mello

Mestranda em Comunicação Social (UERJ), graduada em Jornalismo (PUC-Rio, 1995), com especialização em Marketing Empresarial (UNESA, 2001) e em Mídia, Tecnologia e Novas Práticas Educacionais (PUC-Rio, 2009). Acumula 18 anos de experiência no mercado corporativo, com atuação nas áreas de Comunicação e Marketing em grandes empresas nacionais e multinacionais

RECEBIDO EM: 29/06/2016

ACEITO EM: 30/08/2016 